\title{
Microbe gets toxic response
}

Researchers question the science behind last week's revelation of arsenic-based life.

\section{BY ALLA KATSNELSON}

$\mathrm{D}$ ays after an announcement that a strain of bacteria can apparently use arsenic in place of phosphorous to build its DNA and other biomolecules - an ability unknown in any other organism - some scientists are questioning the finding and taking issue with how it was communicated to non-specialists.

Many readily agree that the bacterium, described last week in Science and dubbed GFAJ-1 (F. Wolfe-Simon et al. Science doi: 10.1126/science.1197258; 2010), performs a remarkable feat by surviving high concentrations of arsenic in California's Mono Lake and in the laboratory. But data in the paper, they argue, suggest that it is just as likely that the microbe isn't using the arsenic, but instead is scavenging every possible phosphate molecule while fighting off arsenic toxicity. The claim at a NASA press briefing that the bacterium represents a new chemistry of life is at best premature, they say.

"It's a great story about adaptation, but it's not ET," says Gerald Joyce, a biochemist at the Scripps Research Institute in La Jolla, California.

At the press briefing, Steven Benner, a chemist at the Foundation for Applied Molecular Evolution in Gainesville, Florida, who was invited to the event to offer outside comment, used the analogy of a steel chain with a tinfoil link to illustrate that the arsenate ion said to replace phosphate in the bacterium's DNA forms bonds that are orders of magnitude less stable. Not only would the organism's DNA have to stay together in spite of the weaker bonds, says Benner, but so would all the molecules required to draw arsenate from the environment and build it into the genetic material. Co-authors of the paper, including Paul Davies, an astrobiologist at Arizona State University in Tempe, have countered that the arsenate bonds could be reinforced by specialized molecules, or that arsenic-based life simply has a higher turnover for molecular disintegration and assembly than does conventional life.

The big problem, however, is that the authors have shown that the organism takes up arsenic, but they "haven't unambiguously identified any arsenic-containing organic compounds", says Roger Summons, a biogeochemist at the Massachusetts Institute of Technology in Cambridge. "And it's not difficult to do," he adds, noting that the team could have directly confirmed or disproved the presence of arsenic in the DNA or RNA using targeted mass spectrometry.

down to conserve phosphate. One calculation in the paper showed that the DNA in arsenategrown cells actually contained 26 times more phosphorus than arsenic.

"I fault the authors for not noticing these things and sorting them out," says Rosemary Redfield, a microbiologist at the University of British Columbia in Vancouver, Canada, whose summary of the paper's problems, posted on her blog on 4 December, has already had more than 30,000 hits. "We shouldn't have to do the thinking for them."

Felisa Wolfe-Simon, a NASA astrobiology research fellow at the US Geological Survey in Menlo Park, California, and the study's lead author, refused to address criticisms. "We are not going to engage in this sort of discussion," she wrote in an e-mail to Nature. "Any discourse will have to be peer-reviewed in the same manner as our paper was, and go through a vetting process so that al discussion is properly moderated."

But Jonathan Eisen, a microbiologist at the University of California, Davis, calls this "ludicrous", after a NASA press release drew media attention with claims of an "astrobiology finding that will impact the search for evidence of extraterrestrial life", a theme that Wolfe-Simon echoed at the

Some researchers suggest that the authors' own data hint at an organism that is simply absorbing and isolating arsenate while making use of the trace phosphates in its environment. For one thing, says Joyce, the paper shows that the organisms appear bloated, and contain large, vacuole-like structures often a sign of sequestered toxic material. The arsenate-grown cells were analysed in their resting phase, which requires less phosphate for survival than does active growth, notes Joyce, and cells grown in high concentrations of arsenate did not seem to contain any RNA - possibly because RNA production had shut briefing. "It is absurd for them to say that they are only going have the discussion in the scientific literature, when they started it," he says.

Ginger Pinholster, a spokeswoman for Science's publisher, the American Association for the Advancement of Science in Washington DC, noted that the journal regards significant responses to high-visibility articles, as well as efforts to replicate the work, as a "key goal of publication". Pinholster also pointed out that the journal's own press summary of the paper made no mention of the search for extraterrestrial life, nor did Science "organize any additional promotional events".

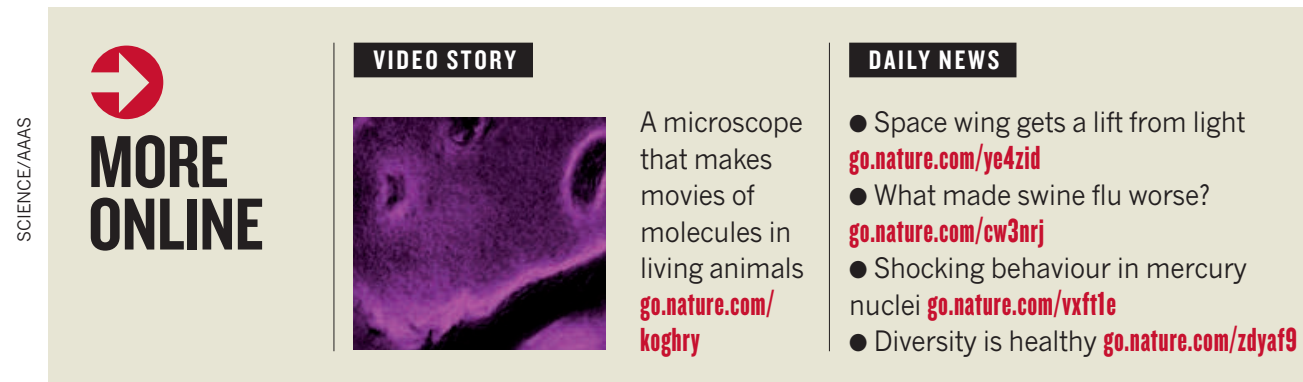

\section{EXPEDITION BLOG}

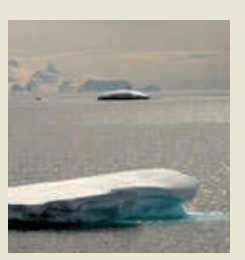

Reporter Jane Qiu visits the Antarctic Peninsula, ground zero for climate change go.nature.com/wspgih 